\title{
Da relação com o Outro às transformações sociotécnicas: desafios ao jornalismo
}

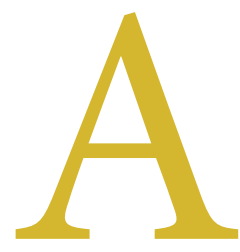

abertura do jornalismo ao reconhecimento do Outro, o modo como se implica com as demandas de cidadãos comuns ou ainda sua participação na promoção de direitos humanos são temáticas cada vez mais exploradas na pesquisa em jornalismo e discutida em práticas jornalísticas. Expressam algumas das formas contemporâneas de referir as expectativas sociais historicamente criadas e dirigidas ao jornalismo e aos relatos que constrói sobre o mundo e os atores que o povoam. Tomamos esta relação da atividade jornalística com a alteridade, em um contexto de profundas transformações sociais e tecnológicas que desafiam o jornalismo e a sociedade, como ponto de partida para apresentar a edição semestral, volume 18, número 2, da revista Estudos em Jornalismo em Mídia. Ela inclui 14 artigos de temas livres, uma entrevista e duas resenhas de livros.

Esta edição inicia justamente abordando a problemática do reconhecimento no âmbito do jornalismo, com artigo "Reportagem e reconhecimento: a alteridade como projeto", de autoria de Reges Schwaab. A partir de uma articulação entre os estudos da reportagem e a filosofia, o pesquisador discute "a reportagem jornalística e sua construção narrativa como devedora do gesto de reconhecimento, mantendo em permanente evidência o Outro como dimensão primeira da comunicação".

A preocupação de pensar a relação do jornalismo com o outro - que é também um sujeito de direitos - aparece através de uma outra visada no artigo de Lynara Ojeda de Souza e Gabriela Cavalcanti Carneiro de Almeida, intitulado "Reflexões sobre a importância dos direitos humanos e jornalismo na atualidade". As pesquisadoras refletem sobre o papel da imprensa na promoção dos direitos humanos, sobre o descrédito que envolve tais práticas na contemporaneidade e como a pauta de temas relacionados a direitos humanos no tratamento jornalístico tem sido interpretada pela sociedade.

A relação do jornalismo com o Outro perpassa ainda o estudo de Tayane Aidar Abib e Mauro Ventura sobre o "desacontecimento noticioso". A noção é vista como "estratégia de narração de fatos não-marcados", que se se interessa pelos "relatos da cotidianidade do homem ordinário, em contraponto aos tradicionais critérios de desvio e proeminência que atravessam a cobertura hegemônica, colhendo das construções de sentidos rotineiras marcas de resistência íntima e social para tessituras intersubjetivas".

Acontecimento político de grande repercussão e consequências na vida política do Brasil, a destituição de Dilma Rousseff da Presidência da República, em 2016, é discutida no artigo de Marcos Paulo da Silva e Raquel de Souza Jeronymo. 
Eles estudam o enquadramento jornalístico construído pelas revistas Veja e IstoÉ durante o processo de impeachment da ex-presidenta, a partir de uma perspectiva de gênero. Através de uma análise multimodal, os pesquisadores acrescentam às funções clássicas de enquadramento o estudo das fontes, dos canais de informação e das estratégias retóricas das práticas jornalísticas. Inferem que o enquadramento realizado "cumpre um papel político desestabilizador no jogo de poder e sofre influências do universo sexista que historicamente caracteriza a política deliberativa no país".

No quinto artigo desta edição da EJM, Rafael Bellan Rodrigues de Souza dedica-se a compreender as contradições do jornalismo "em tempos de desmanche neoliberal, ascensão do capitalismo financeiro, corrosão do trabalho e plataformização da vida social", analisando a práxis jornalística dos dias de hoje em seus elementos dominantes, residuais e emergentes. Reflete sobre "a relação da práxis noticiosa com a vida cotidiana" e avalia "seu potencial no enfrentamento da barbárie social e dos estranhamentos gerados pelo sistema sociometabólico do capital".

Victor Israel Gentilli e Thalita Mascarelo da Silva também se dedicam a estudar transformações no jornalismo, sobretudo no que concerne às relações sociais e de poder envolvendo fontes de informação científicas, vistas como promotoras de notícias e potenciais influenciadoras digitais. $\mathrm{O}$ estudo é fundamentado em dois percursos teóricos: "a emergência de um ecossistema jornalístico" e "o entendimento da territorialidade e da temporalidade como fenômenos articulados com ênfase nas modificações na circulação da informação jornalística, condicionamentos emergentes das sociedades contemporâneas".

As transformações tecnológicas sobre jornalismo e sua produção em diferentes plataformas perpassam vários artigos desta edição. Julio Cesar Lemes de Castro propõe demonstrar que as plataformas algorítmicas são espaços propícios à desinformação, por conta do modo como "suas características tecnológicas são instrumentalizadas por seu modelo de negócios, resultando na prevalência do valor-algoritmo sobre o valor-notícia". Para apreender tal instrumentalização e seus efeitos em termos de desinformação, o autor analisa o modus operandi das plataformas a partir de quatro dimensões: Onimediação desigual; arena de atenção; exposição calibrada; e máquinas de guerra híbrida.

Já Adalton dos Anjos Fonseca propõe pensar uma epistemologia da prática jornalística orientada à imersão. Apoiado em análise de casos de peças jornalísticas nacionais e internacionais premiadas e de entrevistas semiestruturadas com profissionais, de cada peça foram realizadas, o pesquisador sustenta que "uma epistemologia da prática do jornalismo em redes digitais que investe na imersão tem como especificidade modos de operação e uma disponibilidade dos agentes produtivos que valorizam a experiência".

Raquel Ritter Longhi e Lia Gabriela Pagoto, por sua vez, discutem a emergência do efêmero na produção ciberjornalística e analisam a adaptação de conteúdos jornalísticos para o Instagram Story. Buscam identificar de que forma o veículo se adapta à ferramenta nativa da rede social, verificando características da produção deste microformato jornalístico considerando aspectos como volume e frequência; recursos e formas expressivas utilizadas. Indicam que ainda é tímida a exploração dos recursos do microformato.

Na sequência, a pesquisadora Maíra Evangelista de Sousa faz um mapeamento da pesquisa em Jornalismo Móvel (2005-2020) produzida em Programas de Pós-Graduação do Brasil, o que incluiu 16 teses de Doutorado e 44 dissertações de Mestrado, nas quais analisou seis categorias: ano de finalização, Programas de Pós-Graduação, regiões do Brasil, temáticas, suportes e organizações jornalísticas.

"A ecologia midiática do audiovisual em ambientes multiplataformas", assinado por Paulo Eduardo Silva Lins Cajazeira e José Jullian Gomes Souza, é o $11^{\circ}$ artigo desta edição. Os pesquisadores analisam o modo como os aplicativos digi- 
tais, como o Globoplay, têm reconfigurado o sistema de arquivamento da memória audiovisual, cujo acesso é instantâneo, móvel e em multiplataforma.

No âmbito do jornalismo impresso, Juliana Fernandes Teixeira e Allysson Viana Martins recorrem a um produto da ficção para refletir sobre o papel da produção jornalística impressa e de caráter local. No artigo "O Papel do jornalismo impresso na ficção: função social da Gazeta de Tambury na Série After Life da Netflix", Juliana e Allysson destacam que esta produção ficcional problematiza aspectos administrativos, profissionais e deontológicos da produção jornalística, bem como o esforço individual dos profissionais para a renovação do jornalismo.

No penúltimo artigo desta edição da EJM, Vinícius Brito apresenta resultados de sua pesquisa que analisou "notícias" publicadas no período de 1821 a 1858 pelo Diário do Rio de Janeiro (DRJ), considerado precursor do jornalismo contemporâneo no Brasil. É a partir da análise deste caso que o pesquisador "coloca em discussão o 'novo' paradigma do jornalismo, proposta teórica para a imprensa oitocentista, que tende a opor informação e notícia a propaganda e opinião".

Encerrando a seção de artigos, o texto de Eliza Bachega Casadei apresenta estuda "as convocações ao consumo masculino na imprensa a partir do mapeamento das tensões discursivas presentes na definição midiática da andropausa". A partir da Análise de Discurso de Linha Francesa, ela analisa reportagens publicadas em mídias jornalísticas sobre a temática entre janeiro e outubro de 2020, observando as corporalidades mediadas e os discursos de consumo relacionados ao corpo masculino envelhecido.

Na seção Entrevista, a professora e pesquisadora portuguesa Inês Amaral é entrevistada por Ana Marta Flores, doutora pelo PPGJOR/UFSC e também professora e pesquisadora com atuação em Portugal. Como destaca a entrevistadora, a jovem pesquisadora Inês Amaral tem uma trajetória multitemática na área da pesquisa, dentre os quais sociabilidades nas redes sociais digitais, gênero e media; literacia midiática e digital; tecnologias e envelhecimento ativo; audiências e consumos midiáticos na era digital.

A edição é encerrada com duas resenhas. Em "A saga do jornalismo digital segundo o olhar de Luciana Mielniczuk", o mestrando do PPGJOR/UFSC, Matheus Nunes, trata do livro "25 anos de jornalismo digital no Brasil: A contribuição da pesquisadora Luciana Mielniczuk para os estudos no país", organizado por Alciane Baccin, Stefanie C. Silveira e Vivian Belochio. Na segunda resenha, intitulada "Os efeitos das ambiências digitais sobre o social: impactos na comunicação contemporânea", Douglas Barbosa Gomes trata da obra organizada por Elizabeth Saad sob o título "Caminhos da Comunicação: tendências e reflexões sobre o digital".

Somas gratas a todos e todas que contribuíram para tornar possível mais esta edição da revista Estudos em Jornalismo e Mídia. Nosso agradecimento especial aos autores e autoras que escolheram a EJM para publicar seu trabalho, bem como à preciosa colaboração da equipe de avaliadores(as) e de revisores(as) desta edição.

Desejamos uma ótima leitura!

Terezinha Silva e Flávia Guidotti. 